2002 100: 707-709

Prepublished online May 24, 2002;

doi:10.1182/blood-2002-01-0060

\title{
Paternal mosaicism proves the pathogenic nature of mutations in neutrophil elastase in severe congenital neutropenia
}

Phil J. Ancliff, Rosemary E. Gale, Michael J. Watts, Ri Liesner, lan M. Hann, Stephan Strobel and David C. Linch

Updated information and services can be found at:

http://bloodjournal.hematologylibrary.org/cgi/content/full/100/2/707

Articles on similar topics may be found in the following Blood collections:

Brief Reports (1057 articles)

Hematopoiesis and Stem Cells (2389 articles)

Phagocytes (957 articles)

Information about reproducing this article in parts or in its entirety may be found online at:

http://bloodjournal.hematologylibrary.org/misc/rights.dtl\#repub_requests

Information about ordering reprints may be found online at:

http://bloodjournal.hematologylibrary.org/misc/rights.dtl\#reprints

Information about subscriptions and ASH membership may be found online at:

http://bloodjournal.hematologylibrary.org/subscriptions/index.dtl

Blood (print ISSN 0006-4971, online ISSN 1528-0020), is published

semimonthly by the American Society of Hematology, 1900 M St, NW, Suite 200, Washington DC 20036.

Copyright 2007 by The American Society of Hematology; all rights reserved.

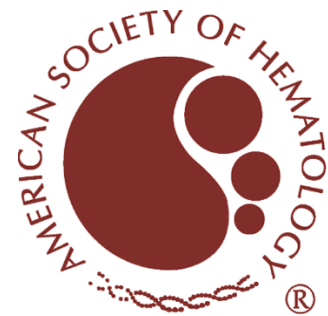




\title{
Paternal mosaicism proves the pathogenic nature of mutations in neutrophil elastase in severe congenital neutropenia
}

\author{
Phil J. Ancliff, Rosemary E. Gale, Michael J. Watts, Ri Liesner, Ian M. Hann, Stephan Strobel, and David C. Linch
}

\begin{abstract}
Heterozygous mutations in neutrophil elastase have been detected in many sporadic cases of congenital neutropenia. However, a convincing pathogenetic mechanism has not been established, and it is unclear whether the effects of the mutant enzyme occur within the cell of production or are paracrine in nature. The healthy father of a patient was demonstrated to be mosaic for his daughter's Cys42Arg
\end{abstract}

elastase mutation. Using semiquantitative polymerase chain reaction, approximately half of his $\mathrm{T}$ cells were shown to carry the mutation in contrast to less than $10 \%$ of neutrophils. Individual hematopoietic colonies grown from peripheral blood were heterozygous for the mutation or were homozygous wild type. These results demonstrate that precursors containing the mutation are selectively lost during myelopoiesis or fail to develop into neutrophils. This is the first in vivo confirmation of the pathogenic nature of elastase mutations in humans. The normal neutrophil count in the father suggests that the mutant elastase does not have paracrine effects. (Blood. 2002;100:707-709)

() 2002 by The American Society of Hematology

\section{Introduction}

Severe congenital neutropenia (SCN) is manifest by persistent severe neutropenia, recurrent bacterial infection, and maturation arrest in the bone marrow at the promyelocyte-myelocyte stage. ${ }^{1}$ Until recently, the pathogenesis of SCN was unknown, but genetic studies have now suggested a causal role for heterozygous mutations in the ELA2 gene encoding neutrophil elastase in approximately three fourths of sporadic cases. ${ }^{2,3}$ However, a convincing pathogenetic mechanism has not yet been established; neutrophil elastase knock-out mice are not neutropenic, ${ }^{4,5}$ and preliminary knock-in experiments have failed to produce an SCN phenotype. ${ }^{6}$ Recently, doubts have been raised as to whether the mutations described are actually sufficient to cause the phenotype of SCN. ${ }^{7}$

We present here evidence of mosaicism for an ELA2 mutation in the hematologically healthy father of a child with SCN, strongly supporting the pathogenic nature of this mutation in myelopoiesis.

\section{Study design}

\section{Case history}

The patient had typical SCN diagnosed in infancy. Current white blood cell (WBC) count at 4 years of age is $3.52 \times 10^{9} / \mathrm{L}$ (neutrophils, $0.04 \times 10^{9} / \mathrm{L}$; monocytes, $0.63 \times 10^{9} / \mathrm{L}$ ). Cytogenetic analysis results have always been normal. She had no numerical or clinical response to granulocyte colony stimulating factor (G-CSF), even to doses greater than $100 \mu \mathrm{g} / \mathrm{kg}$ per day, or to the combination of prednisolone and G-CSF. Her parents were unrelated and of northern European origin and had normal full blood counts and white cell differentials (father: WBC, $7.03 \times 10^{9} / \mathrm{L}$; neutrophils, $4.18 \times 10^{9} / \mathrm{L}$; monocytes, $0.61 \times 10^{9} / \mathrm{L}$ ). Neither had a history of recurrent infections.

\section{Mutational analysis}

The ELA2 gene was amplified by polymerase chain reaction (PCR) and sequenced as described previously. ${ }^{3}$ To confirm the presence of the mutation, a fragment covering nucleotides 1768 to 1959 (GenBank accession number Y00477) was amplified using a $3^{\prime}$ mismatch primer that introduced a SacII restriction endonuclease (RE) digestion site in mutant alleles only. Semiquantitative PCR was performed with a $\gamma-{ }^{32} \mathrm{P}-$ endlabeled forward primer and 25 cycles of amplification on DNA from cells purified from peripheral blood by density gradient centrifugation and isolation with the MiniMACS magnetic bead system (Miltenyi Biotec, Bisley, United Kingdom). SacII-digested products were electrophoresed through $6 \%$ denaturing polyacrylamide gels, and the bands were quantified by densitometry.

PCR fragments covering the mutation (nucleotides 1768-1992) and the common C/A polymorphism at nucleotide $4890^{8,9}$ (nucleotides 4599-5133) were subcloned, and individual colonies were analyzed by mismatch PCR and RE digestion using $S a c \mathrm{II}$ and $B s p \mathrm{EI}$, respectively.

\section{Peripheral blood colony assays}

Fresh mononuclear cells $\left(50 \times 10^{3} / \mathrm{mL}\right)$ were cultured in semisolid media (Methocult H4230; Stem Cell Technologies, Vancouver, BC, Canada) supplemented with G-CSF $(25 \mathrm{ng} / \mathrm{mL})$, granulocyte macrophage-CSF $(25 \mathrm{ng} / \mathrm{mL})$, interleukin-3 (30 ng/mL), stem cell factor $(10 \mathrm{ng} / \mathrm{mL})$, and erythropoietin (3 $\mathrm{U} / \mathrm{mL}$ ). Individual colonies were plucked at day 12 of culture, lysed with proteinase $\mathrm{K}\left(1.2 \mu \mathrm{g}\right.$ in $20 \mu \mathrm{L}$ detergent lysis buffer) for 60 minutes at $55^{\circ} \mathrm{C}$ and then were analyzed by PCR and RE digestion as before.
From the Departments of Haematology and Immunology, University College London and Great Ormond Street Children's Hospital, London, United Kingdom.

Submitted January 9, 2002; accepted March 1, 2002. Prepublished online as Blood First Edition Paper, May 24, 2002; DOI 10.1182/blood-2002-01-0060.

Supported by the Roald Dahl Foundation (P.J.A.), and Amgen Ltd (unrestricted educational grant) (P.J.A.).
Reprints: Phil Ancliff, Department of Haematology, University College London, 98 Chenies Mews, London, WC1E 6HX, United Kingdom; e-mail: p.ancliff@ucl.ac.uk.

The publication costs of this article were defrayed in part by page charge payment. Therefore, and solely to indicate this fact, this article is hereby marked "advertisement" in accordance with 18 U.S.C. section 1734.

(c) 2002 by The American Society of Hematology 


\section{Results and discussion}

\section{Mutational analysis}

Sequencing of the ELA2 gene of the patient identified a 1929T $>$ C mutation that would lead to a Cys42Arg substitution. PCR and RE digestion confirmed that she was heterozygous for the mutation and had approximately 50\% mutant DNA in her peripheral blood (Figure 1A). Her mother and 55 healthy controls had only wild-type alleles. However, preliminary analysis of the total white cells from her father detected a low level of the mutant. Semiquantitative PCR on DNA from a fresh peripheral blood sample in March demonstrated that his $\mathrm{T}$ cells had $28.5 \% \pm 6.1 \%$ (mean \pm SD of 4 analyses) mutant alleles, whereas his neutrophils had $4.6 \pm 1.2 \%(n=4)$ mutant alleles. These results did not change significantly with time. In November his $\mathrm{CD}^{+}$cells had $38.4 \% \pm 0.9 \%(\mathrm{n}=2)$, neutrophils had $0.4 \% \pm 0.7 \%(\mathrm{n}=3)$, and $\mathrm{CD} 14^{+}$cells had $27.3 \% \pm 3.4 \%(\mathrm{n}=2)$ mutant alleles. The patient had $54.5 \% \pm 2.3 \%(\mathrm{n}=7)$ mutant alleles (Figure 1A). These results suggested that the father was a somatic mosaic for his daughter's neutrophil elastase mutation and had selective loss of myeloid cells expressing the mutation.

\section{Proof of mosaicism}

To prove the probable mosaicism, 2 PCR fragments were subcloned from DNA from the father's $\mathrm{CD}^{+}$cells and neutrophils (March samples). One fragment covered the 1929T $>$ C mutation identified in the affected child. The other fragment covered the previously reported $4890 \mathrm{C}>\mathrm{A}$ (Ser173Ser) silent polymorphism ${ }^{8,9}$ for which the father was heterozygous but the daughter homozygous $\mathrm{C}$, thus acting as an internal control. Attempts to use long-range PCR to amplify both sites within one fragment were unsuccessful, possibly because of the high GC content within that 3365-bp fragment. Analysis of individual clones showed that the $\mathrm{C}$ and $A$ alleles at the polymorphic site were equally distributed in the clones from $\mathrm{CD}^{+}$cells and neutrophil DNA, as would be expected for a polymorphism (Table 1). However, only one fourth of clones from $\mathrm{CD}^{+}$cells had the mutant $\mathrm{C} 1929$ allele.

Expression of neutrophil elastase is exclusively limited to cells of the myeloid lineage and thus would not exert a functional

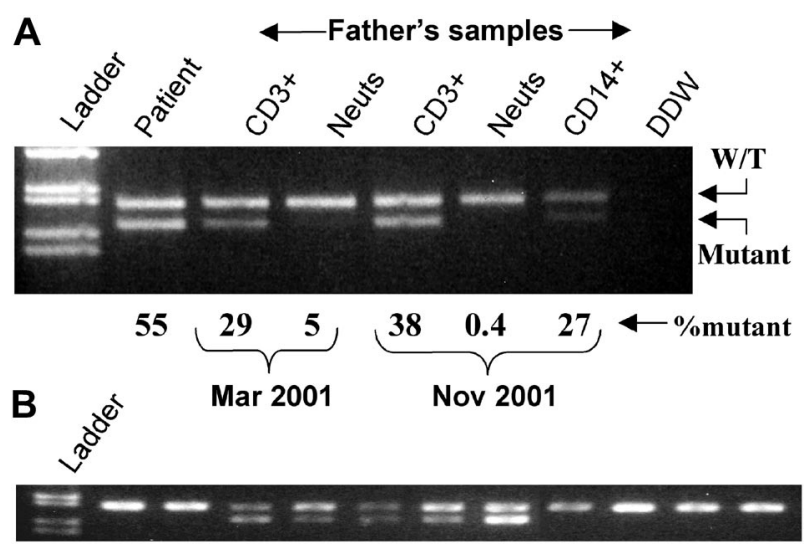

Figure 1. Mismatch PCR and restriction enzyme analysis. (A) DNA prepared from total white blood cells from the patient and purified cellular fractions from the father Percentages of mutant DNA are derived from radioactive PCR analysis. Cell purity (November only): $\mathrm{CD}^{+}$, greater than $98 \%, \mathrm{CD} 14^{+}, 85 \%$ (by flow cytometry) neutrophils, greater than $97 \%$ (400 cell differential). (B) Representative individual erythroid colonies grown in vitro from the father's blood mononuclear cells. Neuts indicates neutrophils; W/T, wild-type; DDW, double deionized water.
Table 1. Analysis of individual subclones derived from paternal peripheral blood cell DNA and in vitro colonies for the presence of the 1929T >C mutation and $4890 \mathrm{C}>\mathrm{A}$ polymorphism

\begin{tabular}{|c|c|c|c|c|}
\hline & \multirow{3}{*}{\multicolumn{2}{|c|}{$\begin{array}{c}\text { 1929T }>\text { C mutation } \\
\text { C1929 clones } \\
\text { (colonies)/total } \\
\text { analyzed }\end{array}$}} & \multirow{2}{*}{\multicolumn{2}{|c|}{$\begin{array}{c}4890 \mathrm{C}>\mathrm{A} \\
\text { polymorphism }\end{array}$}} \\
\hline & & & & \\
\hline & & & \multicolumn{2}{|c|}{$\begin{array}{l}\text { A4890 clones/total } \\
\text { clones analyzed }\end{array}$} \\
\hline & No. & $\%$ & No. & $\%$ \\
\hline \multicolumn{5}{|c|}{ Peripheral blood cells } \\
\hline $\mathrm{CD}^{+}$ & 13 of 54 & $24^{*}$ & 27 of 53 & 48 \\
\hline Neutrophils & 6 of 84 & $7^{*}$ & 16 of 36 & 44 \\
\hline \multicolumn{5}{|l|}{ In vitro colonies } \\
\hline BFU-E & 33 of 58 & 57 & - & - \\
\hline CFU-GM & 14 of 34 & 41 & - & - \\
\hline
\end{tabular}

*Difference in the percentage of mutant clones derived from $\mathrm{CD}^{+}$and neutrophil DNA is statistically significant $(P<.001)$.

selection pressure on $\mathrm{T}$ cells. ${ }^{10,11}$ These results indicated that one half of the father's nonmyeloid cells contained the mutation; therefore, the mutation arose at the first mitotic division after fertilization on his allele with $\mathrm{C}$ at nucleotide 4890. Furthermore, the low proportion of $\mathrm{C} 1929$ clones from neutrophils (approximately $7 \%$ ) suggested that cells expressing the elastase mutation had been selectively lost at an earlier stage in myelopoiesis.

Further proof of mosaicism was obtained from analysis of individual colonies cultured in vitro from the father's peripheral blood mononuclear cells. Normal numbers of colonies were obtained-608 erythroid burst-forming units (BFU-E) and 231 granulocyte macrophage colony-forming units (CFU-GM) per milliliter peripheral blood (median \pm SD for 20 healthy controls analyzed on 4 separate occasions $=356 \pm 280$ and $95 \pm 127 / \mathrm{mL}$, respectively). PCR analysis confirmed the presence of wild-type and heterozygous colonies in both lineages (Table 1, Figure 1B). This apparently normal myeloid growth (by colony count) is consistent with growth factor-supplemented in vitro studies previously reported in SCN patients ${ }^{12,13}$ and may be explained by the increased proportion of macrophages in colonies from such patients. Cells of the monocyte-macrophage lineage express much lower levels (approximately 6\% that of neutrophils) ${ }^{14}$ of neutrophil elastase and thus would be less susceptible to any potential toxic effects of the mutant enzyme.

Recent studies have demonstrated that mosaicism is a relatively common event in several genetic disorders. ${ }^{15-17}$ For example, in a recent study of hemophilia A, evidence of mosaicism was found in 8 of 61 (13\%) of families studied. ${ }^{15}$ In the case presented here, a neutrophil elastase mutation acquired in the father at the embryonic 2-cell stage had been passed on to his daughter, who was heterozygous for the mutation and had classical SCN. The phenotype of the child was unusually severe in that she failed to respond to G-CSF therapy. Mutations in the extracellular domain of the G-CSF receptor have been reported in $2 \mathrm{SCN}$ patients who similarly had no response to G-CSF, ${ }^{18,19}$ but no evidence for such a mutation was found in the present case (data not shown). The hematologically normal phenotype of the father could be explained by the almost complete absence of mutation-expressing neutrophils in his blood, presumably because neutrophils never developed from stem cells expressing the ELA2 mutant or were destroyed before entering the circulation. This result not only provides the first in vivo confirmation of the pathogenic role of mutant neutrophil elastase in humans, it also argues against a paracrine mechanism for the detrimental activity of the mutant enzyme. 
From www.bloodjournal.org at UCL Library Services on August 20, 2008. For personal use only.

\section{References}

1. Welte K, Dale D. Pathophysiology and treatment of severe chronic neutropenia. Ann Hematol. 1996;72:158-165

2. Dale DC, Person RE, Bolyard AA, et al. Mutations in the gene encoding neutrophil elastase in congenital and cyclic neutropenia. Blood. 2000;96: 2317-2322.

3. Ancliff PJ, Gale RE, Liesner R, Hann IM, Linch DC. Mutations in the ELA2 gene encoding neutrophil elastase are present in most patients with sporadic severe congenital neutropenia but only in some patients with the familial form of the disease. Blood. 2001;98:2645-2650.

4. Belaaouaj A, McCarthy R, Baumann M, et al. Mice lacking neutrophil elastase reveal impaired host defense against Gram-negative bacterial sepsis. Nat Med. 1998;4:615-618.

5. Tkalcevic J, Novelli M, Phylactides M, Iredale JP, Segal AW, Roes J. Impaired immunity and enhanced resistance to endotoxin in the absence of neutrophil elastase and cathepsin G. Immunity. 2000;12:201-210.

6. Grenda DS, McLemore ML, Johnson SE, Horwitz $M$, Link DC. Mice expressing neutrophil elastase bearing the V72M mutation found in patients with severe congenital neutropenia do not display an SCN phenotype [abstract]. Blood. 2001;98:440.

7. Germeshausen M, Schulze H, Ballmaier M, Zeidler $\mathrm{C}$, Welte K. Mutations in the gene encoding neutrophil elastase (ELA2) are not sufficient to cause the phenotype of congenital neutropenia. Br J Haematol. 2001;115:222-224.

8. Takahashi H, Nukiwa T, Yoshimura K, et al. Structure of the human neutrophil elastase gene. J Biol Chem. 1988;263:14739-14747.

9. Horwitz M, Benson KF, Person RE, Aprikyan AG, Dale DC. Mutations in ELA2, encoding neutrophil elastase, define a 21-day biological clock in cyclic haematopoiesis. Nat Genet. 1999;23:433-436.

10. Fouret $P$, du Bois RM, Bernaudin JF, Takahashi $H$, Ferrans VJ, Crystal RG. Expression of the neutrophil elastase gene during human bone marrow cell differentiation. J Exp Med. 1989;169: 833-845.

11. Gullberg U, Bengtsson N, Bulow E, Garwicz D, Lindmark A, Olsson I. Processing and targeting of granule proteins in human neutrophils. J Immunol Methods. 1999;232:201-210.

12. Coulombel L, Morardet N, Veber F, et al. Granulopoietic differentiation in long-term bone marrow cultures from children with congenital neutropenia. Am J Hematol. 1988;27:93-98.

13. Hestdal K, Welte K, Lie SO, Keller JR, Ruscetti FW, Abrahamsen TG. Severe congenital neutropenia: abnormal growth and differentiation of myeloid progenitors to granulocyte colony-stimulating factor (G-CSF) but normal response to G-CSF plus stem cell factor. Blood. 1993;82: 2991-2997.
14. Campbell EJ, Silverman EK, Campbell MA. Elastase and cathepsin $\mathrm{G}$ of human monocytes: quantification of cellular content, release in response to stimuli, and heterogeneity in elastasemediated proteolytic activity. J Immunol. 1989; 143:2961-2968.

15. Leuer M, Oldenburg J, Lavergne JM, et al. Somatic mosaicism in hemophilia $A$ : a fairly common event. Am J Hum Genet. 2001;69:75-87.

16. Ruggieri M, Huson SM. The clinical and diagnostic implications of mosaicism in the neurofibromatoses. Neurology. 2001;56:1433-1443.

17. Sippel KC, Fraioli RE, Smith GD, et al. Frequency of somatic and germ-line mosaicism in retinoblastoma: implications for genetic counseling. Am J Hum Genet. 1998;62:610-619.

18. Ward AC, van Aesch YM, Gits J, et al. Novel point mutation in the extracellular domain of the granulocyte colony-stimulating factor (G-CSF) receptor in a case of severe congenital neutropenia hyporesponsive to G-CSF treatment. J Exp Med. 1999;190:497-507.

19. Sinha S, Watkins S, Corey SJ. Genetic and biochemical characterization of a deletional mutation of the extra-cellular domain of the human G-CSF receptor in a child with severe congenital neutropenia unresponsive to neupogen [abstract] Blood. 2001;98:440. 